\title{
Learning to Be Questioners: Remembering Paul Wellstone, a Pioneer and Champion of Experiential Education
}

\author{
A m y $\quad$ u n d e r I a n d \\ Higher Education Consortium for Urban Affairs, St Paul, MN
}

Paul Wellstone carried into politics the same values he espoused as an educator. He inspired citizens, including so many students, to see themselves as subjects of history. "Politics," he said, "is what we create out of what we do, what we hope for, what we dare to imagine." He believed education to be a tool for developing an active citizenry, for nourishing a robust democracy, for helping students to form values and imagine their futures. His extraordinary life of commitment, as expressed in both the political and educational leadership, was rooted in a passion for learning from experience.

What made Wellstone a great senator and earned him the admiration of people across the political spectrum is exactly what made him a great teacher. He sought out, respected, and learned from diverse perspectives. As a teacher, he wanted students to experience peoples' lives, to hear their stories, to explore the real world in all its complexity and simplicity, with a belief that whatever path they would take, they would carry with them a curiosity and genuine interest in others that would make our world a better place.

Wellstone described his own approach to teaching in a St. Paul Pioneer Press article entitled "Super Teachers Challenge Students to Stretch Minds, Goals": "I make a point of telling students that I'm not neutral. I have values that inform me. I ask students to present their own thorough analysis regardless of their views, and I raise lots of questions and insist that each student locate him/herself in relation to the material. There is a real distinction between educating and politicizing. I don't think that educating is telling a student what they should think. You need to be respectful. It's important to make learning personal." He would 
press students: "What's feasible? What's realistic? What's the cost? Most important, what's fair and just?"

After Wellstone's death, many tributes came from his former students at Carleton College, where he taught political science. They recalled the way he wove classroom and field education together into learning experiences that are still with them twenty and thirty years later. He drew upon the learning laboratory of the community surrounding Carleton College. Students researched the welfare system in rural Rice County, for example, but he also had them attend organizational meetings in the community. Engaged in the reality of policy struggles, he had students put organizing theory to the test. As one of his former students recalled, "We learned that 25 welfare mothers could research a policy and understand it. We learned that those same mothers with kids in tow could close down a county courthouse until someone would recognize them. We learned that compromise and negotiation are a part of organizing. In $\mathrm{Mr}$. Wellston's classes we read the theory of organizing and practiced the art" (Jonathan Lange, quoted in the Baltimore Sun, "Senator's Disciples Carry on His Work," November 4, 2002).

Wellstone's influence also lives on in the educational innovations he helped to create. Thirty years ago, while teaching at Carleton College, Wellstone joined in organizing faculty from area colleges to create a community-based education program to provide a critical complement to the interdisciplinary curriculums that were just then beginning to develop. The experiment was a full-time immersion of students in the community while they studied issues those communities were facing. Students lived in the community, learned from the community and from people's lives. They learned that the perspectives of politicians, community organizers, and residents added an important dimension to the theories discussed in the classroom. They grappled with testing textbook theories as they explored the ways in which people were trying to address important social issues. Students were engaged, and they began to imagine ways in which they, too, could touch history. "In 1970, I was ready to drop out of college because I couldn't see the relevance of my studies to the burning issues of the day," recalls Pam Costain, then a student of Paul Wellstone. His encouragement to "get out there and make connections" by participating in this innovative experiential educational program propelled Pam through college and transformed her life forever. (In 2002, Costain left her 
post as executive director of the Resource Center of the Americas to work in Wellstone's reelection campaign.)

Seeing the impact on students and the powerful role that experience played in education, Wellstone helped to transform the original experiment in experiential education into a permanent association of colleges and universities in order to assure the continuation of programs in which students could engage in the most pressing social issues of the day. The Higher Education Consortium for Urban Affairs (HECUA) was incorporated in 1971. Bold in its day, HECUA now is a resource and partner helping institutions activate their civic missions with wide-ranging programs. These programs engage students, faculty and community organizations in locations as diverse as Minneapolis-St. Paul, the southern United States, Latin America, Northern Ireland, Bangladesh, and Scandinavia.

The actions taken by Paul Wellstone and his fellow faculty and college presidents stemmed from his vision and commitment about teaching and learning. There was an urgency for higher education to respond to incendiary times with relevancy to issues of the day. Neighborhoods were on fire; students were disillusioned and dropping out of school. The fires today may be less apparent, but the indicators of need for change are present and as real as ever. Experiential education now is far more common and seen in its many forms, and it is increasingly recognized as vehicle for achieving the civic mission of the liberal arts, of helping students locate themselves in the world.

The methods of learning Wellstone practiced in teaching he also brought to his work as a US Senator. Wellstone not only renewed his energy and commitment by continually connecting with people, it was through a multitude of conversations with a range of people that he shaped his legislative agenda. It was not enough to listen to expert advice from policy wonks or lobbyists. For Wellstone, legislative vision was grounded in the realities of ordinary people.

Although his work on domestic issues of equality and justice may be best known, Wellstone's forays into foreign policy were informed by the same methods of gathering knowledge. When he led a fact-finding mission to Colombia in November of 2000, he listened to the experiences of human rights leaders and civilians as well as government officials. Following his return, Wellstone, who had been one of the few senators 
originally to oppose Plan Colombia, became one of the country's leading spokespersons for a fundamental change in the Untied State's foreign policy towards Colombia.

Perhaps Paul Wellstone's most enduring legacy is the cadre of his former students and the 3,000 HECUA alumni who are active in all sorts of pursuits throughout the world. They are active citizens, civic leaders and civil servants, architects of a changing world. They run and staff human rights, advocacy and refugee programs, community development and environmental movements, planning and human services departments, chemical dependency and hospice programs, educational and philanthropic programs. They are teachers.

In this tragedy is an occasion to remind us that our work is part of something larger. Paul Wellstone's life serves as a powerful example, and his death strikes a deep chord that too many of us regularly suppress - a call to a life of commitment, to be a person of principle and conviction in world that has too little of both. The hope lies in this reflection and what we carry forward in our own lives and work as educators and subjects of history. 